Article

\title{
Accessibility of Assistive Technologies as a Factor in the Successful Realization of the Labor Potential of Persons with Disabilities: Russia's Experience
}

\author{
Olga Aleksandrova ${ }^{1,2}$ and Yulia Nenakhova ${ }^{1, *(1)}$ \\ 1 Institute of Socio-Economic Studies of Population, Russian Academy of Sciences (ISESP RAS), \\ 32, Nakhimovsky prospect, 117218 Moscow, Russia; a762rab@mail.ru \\ 2 Department of Sociology, History and Philosophy, the Financial University under the Government of the \\ Russian Federation, 49, Leningradsky prospect, 125993 Moscow, Russia \\ * Correspondence: yulia-nenakhova@yandex.ru; Tel.: +7-977-387-70-83
}

Received: 31 July 2019; Accepted: 14 October 2019; Published: 15 October 2019

\begin{abstract}
In this article, the accessibility of assistive technologies is considered as a factor in the realization of the labor potential of persons with disabilities and is analyzed in the context of the accessibility of the urban environment, the enterprise environment, and directly at the workplace. The analysis was based on data from two studies, which were devoted to persons with disabilities in Moscow's labor market, but the identified problems were not specific to the capital region. In Russian provinces, these issues are even more acute due to the scarcity of regional budgets and the populations' lower standards of living. The results showed that there were contradictions and problems in each of the considered aspects of this problem. In terms of quantity, the availability of assistive technologies to persons with disabilities is growing, but modern assistive technologies are often not accessible to disabled people because of the high cost and specifics of the public procurement system. Among other barriers to the use of modern assistive technologies by persons with disabilities are ignorance and conservatism of employees of the medical and social expertise systems. The urban environment and urban transport have become more adapted to the needs of disabled people, but existing improvements are far from being sufficient, and many of them are imitative. The State declares the need to include persons with disabilities in the labor sphere, but at the same time insufficiently stimulates employers to create adapted workplaces and does not support enterprises specializing in providing employment for people with disabilities. All of these factors confirm the need for an integrated approach to study the implementation processes of ATs.
\end{abstract}

Keywords: persons with disabilities; employment; assistive technologies; accessibility of environment; adapted workplaces

\section{Introduction}

Recently, the global trend has shown a shift from an emphasis on passive forms of support for persons with disabilities toward their rehabilitation and integration into society. In this regard, assistive technologies are especially important. The World Health Organization (WHO) emphasizes the collective nature of this term, covering a variety of tools and services designed to maintain or expand the functionality and autonomy of people with disabilities. As defined by the World Health Organization, assistive devices and technologies are such devices and technologies "whose primary purpose is to maintain or improve an individual's functioning and independence to facilitate participation and to enhance overall well-being. They can also help prevent impairments and secondary health conditions. Examples of assistive devices and technologies include wheelchairs, prostheses, 
hearings aids, visual aids, and specialized computer software and hardware that increase mobility, hearing, vision, or communication capacities" [1]. Much attention to assistive technology is given in the United Nations documents (Convention on the Rights of Persons with Disabilities, Standard Rules on the Equalization of Opportunities for Persons with Disabilities), obliging countries to undertake or promote research of assistive technologies and to promote the availability and use of new information and communication technologies, mobility aids, and devices, while giving priority to technologies at an affordable cost [2].

At the same time, various scientific studies point to a lack of assistive technology worldwide, even in some high-income countries. At present, the assistive technology industry is characterized by its small size and high specialization and primarily serves markets with a high income at the population level. There is a lack of government funding and research. This situation prompted WHO to adopt a resolution in 2018 entitled "Improving Access to Assistive Technology", which is designed to encourage State parties to take more active steps in this area [3].

In the Union of Soviet Socialist Republics, the approach of shifting the emphasis from passive forms of support for persons with disabilities to their rehabilitation and integration into society was first recorded in the 1990 State Policy on Persons with Disabilities and the Law, "On the Basic Principles of Social Protection of Disabled Persons in the USSR" [4]. The law declared the duty of the state to create the necessary conditions for individual development and the realization of the creative and productive abilities of people with disabilities. However, the political and economic changes that began in 1992 postponed the implementation of this approach [5]. The Law "On Social Protection of Disabled Persons in the Russian Federation", adopted in 1995, contained a provision stating that technical means of rehabilitation are provided at the expense of the federal budget [6]. In 2005, the government of the Russian Federation approved the "Federal List of Rehabilitation Measures, Technical Means of Rehabilitation and Services Provided to Persons with Disabilities", which included 23 sets of technical equipment demanded by the largest groups of people with disabilities [7]. According to the law, the provision of technical rehabilitation devices to people with disabilities is carried out on the basis of individual rehabilitation and habilitation programs (IPRH), which are formed by medical and social expertise institutions (ITU), and is regulated by the Rules to provide people with disabilities with technical rehabilitation devices approved by the Russian Government in 2008 [8]. According to the Rules, a person with a disability is provided, free of charge, with the technical devices of rehabilitation recommended by the IPRH by the organization selected for this purpose by the Social Insurance Fund of the Russian Federation. At their own expense, a person with a disability can purchase a technical rehabilitation device recommended by the IPRH using any organization, while the amount of compensation for expenses incurred by them is determined based on the cost of a similar device ordered by the Social Insurance Fund.

Today, Russia is in the process of actively introducing assistive technologies. According to the Ministry of Labor and Social Protection of Russia, in the period from 2009 to 2017, there was a positive trend regarding the volume of provision of technical means of rehabilitation to disabled people in all major groups (Table 1) [9]. This trend was associated with the implementation of the State program of assistance to people with disabilities called "Accessible Environment", and not with the increase in the number of people with disabilities; according to the Federal State Statistics Service, the total number of people with disabilities decreased during this period from 13,074,000 to $12,924,000$. 
Table 1. Information on technical means of rehabilitation and prosthetic and orthopedic products that the State provides to people with disabilities (pieces) ${ }^{1}$.

\begin{tabular}{|c|c|c|c|c|c|}
\hline & 2009 & 2011 & 2013 & 2015 & 2017 \\
\hline $\begin{array}{l}\text { Support and tactile canes, crutches, } \\
\text { supports, and handrails }\end{array}$ & 29,294 & 434,628 & 435,189 & 404,261 & 310,575 \\
\hline $\begin{array}{l}\text { Wheelchairs with manual drive or } \\
\text { with electric drive, small-sized }\end{array}$ & 89,930 & 149,086 & 140,696 & 143,638 & 140,466 \\
\hline Chairs with sanitary facilities & 38,704 & 70,184 & 60,741 & 64,786 & 49,553 \\
\hline Prostheses & 414,435 & 575,368 & 585,317 & 676,743 & 655,510 \\
\hline Orthopedic shoes & 609,579 & 787,010 & 869,846 & 984,503 & 859,027 \\
\hline $\begin{array}{l}\text { Anti-decubitus mattresses } \\
\text { and pillows }\end{array}$ & 49,794 & 82,737 & 87,965 & 89,697 & 69,700 \\
\hline $\begin{array}{l}\text { Accessories for dressing, undressing, } \\
\text { and grabbing objects }\end{array}$ & 626 & 1457 & 1780 & 2408 & 2305 \\
\hline Special clothes & 2110 & 4767 & 3389 & 1893 & 4041 \\
\hline $\begin{array}{l}\text { Special devices for reading "talking } \\
\text { books" and for optical correction of } \\
\text { low vision }\end{array}$ & 29,488 & 33,547 & 27,462 & 33,259 & 23,957 \\
\hline Dog guides with a set of equipment & 60 & 62 & 61 & 49 & 64 \\
\hline $\begin{array}{l}\text { Medical thermometers and } \\
\text { tonometers with speech output }\end{array}$ & 27,986 & 30,290 & 22,257 & 24,195 & 19,563 \\
\hline $\begin{array}{l}\text { Light and vibration sound } \\
\text { signaling devices }\end{array}$ & 22,528 & 21,076 & 14,933 & 21,617 & 26,116 \\
\hline Hearing aids & 67,670 & 95,030 & 83,780 & 113,706 & 146,829 \\
\hline Teletext television sets & 17,734 & 12,266 & 7703 & 11,243 & 19,307 \\
\hline Text output telephone devices & 20,473 & 13,896 & 9224 & 11,457 & 17,836 \\
\hline Voice creation devices & 560 & 844 & 973 & 1009 & 1216 \\
\hline Colostomy bags and urine bags & $12,498,011$ & $21,045,290$ & $25,504,771$ & $38,814,872$ & $48,458,619$ \\
\hline Absorbent underwear and diapers & $138,776,777$ & $321,620,648$ & $378,073,893$ & $356,686,488$ & $345,834,207$ \\
\hline Sign language translation services & 336,288 & 311,585 & 254,804 & 458,266 & 489,227 \\
\hline
\end{tabular}

Thus, in quantitative terms, the provision of ATs to people with disabilities is growing. However, the low quality of the assistive technologies provided (for example, when ramps for people with disabilities are placed, but are placed at too steep an angle), the technical characteristics of the urban environment, and insufficient equipment with additional technical means, without which assistive technologies for the disabled become ineffective, retain certain problems regarding the availability of assistive technologies [10].

One of the most important areas of personal self-fulfillment is the sphere of labor. It is not by chance that among the 17 sustainable development goals proclaimed by the $\mathrm{UN}$, the goal is to achieve full and productive employment and decent work for all, including the disabled, by 2030 [11]. In turn, $\mathrm{WHO}$, among the various positive effects of using assistive technologies by persons with disabilities, marked the opportunity to get an education and enter the labor market and thereby avoid isolation and poverty. Therefore, the accessibility of assistive technologies is considered in this article as a factor in the realization of labor potential of persons with disabilities. The relevance of this issue for Russia is confirmed by the relatively low level of their employment; while in developed economies, up to half of disabled people are employed [12] (p. 666), in Russia, according to the Federal State Statistics Service, the proportion of employed people in regard to the total number of people of working age with disabilities in 2017 amounted to 17.0\% [13], and the proportion of disabled workers in regard to the total number of disabled people registered with the Pension Fund of Russia was 14.3\% in 2018 [14]. 
Despite the fact that the efforts of Russian authorities to improve employment rates of persons with disabilities were significantly intensified after the ratification of the UN Convention on the Rights of Persons with Disabilities in 2012, this situation remains unchanged. A federal law that passed in 2014 amended 25 federal regulatory and legal acts related to the creation of a barrier-free environment of informational exchange between employment services and medical and social expertise services, etc. [15]. The State program entitled "Accessible Environment" (valid until 2020) also intended to fulfill the obligations related to the ratification of the Convention. In addition to the measures taken regarding the creation of a barrier-free environment and improving information and communication support, etc., this program provides financial support to public organizations of persons with disabilities concerning implementation of programs promoting employment opportunities for persons with disabilities, including job placement and ensuring the accessibility of new workplaces [16]. At the beginning of 2017, the Minister of Labor and Social Protection set a goal to raise the employment rate of people with disabilities up to $50 \%$ by 2020 [17]. However, without increasing the availability of assistive technologies, this goal seems impossible to achieve in practice. The purpose of this article is to analyze the provision of assistive technologies to people with disabilities in Russia and to analyze and address the related issues.

\section{Materials and Methods}

The analysis of the impact of assistive technology availability on the employment of people with disabilities was based on the data from a comprehensive sociological study conducted in 2018 under the guidance and with the participation of the authors. This study focused on persons with disabilities in the Moscow labor market. Other research results are contained in monograph Disabled people employment in the capital of Russia: the problems and solutions [18]. The monograph reveals the problems of the education of persons with disabilities, thanks to which the labor potential is formed, the problems of their motivation and the influence of their immediate environment (including parents) on the motivation of people with disabilities to look for a job, the problems in organizing the work of employment services, as well as the problems in organizing the work of special organizations conducting an appropriate examination of the labor capabilities of persons with disabilities and recording labor recommendations for persons with disabilities, etc. The problem of assistive technologies was not considered in the monograph.

The research toolkit included several sociological methods, including a mass (questionnaire) survey of persons with disabilities, an expert survey in the form of in-depth expert interviews, and content analysis of media materials. In particular, for the purpose of content analysis of media materials on the employment of people with disabilities in Moscow, 250 thematic materials were studied that appeared in 17 media outlets from 1 January 2017 to 1 June 2018. These appeared on three television channels (two federal and one regional), on two major radio stations, in six socio-political print media publications (three newspapers from the top 10 most-cited Russian newspapers and three newspapers from the top-20 most-cited newspapers in Moscow and the Moscow region), in two thematic print media publications (charity newspaper Russky Invalid and Nadezhda (Hope)-newspaper of the All-Russian Society of Disabled People), and in four Internet resources that are in the top 30 most-cited Internet resources in Russia [19]. Based on the results of media content analysis, as well as the analysis of foreign experience, a sociological toolkit for a questionnaire and an expert survey was formed. A mass survey (questionnaire) included answers of more than 1000 people with disabilities. For a mass survey, a questionnaire was developed from 48 questions, which were thematically divided into 4 blocks. An expert survey in the form of in-depth structured interviews assumed consideration of the opinions of 4 groups of experts, namely, heads of societies of persons with disabilities, employers, heads of rehabilitation centers and vocational education institutions, and employees of non-governmental organizations that assist in the employment of persons with disabilities. A total of 24 interviews were analyzed. 
Therefore, this article uses the data from a study conducted with the participation of the authors in 2017. The toolkit used for this purpose included a mass survey (questionnaire) of the visitors to the City Employment Service (including people with disabilities and other vulnerable groups in the labor market), and also an expert survey in the form of in-depth structured interviews with heads of district departments of the Moscow Employment Service.

\section{Results}

Considering the chosen focus of the research, i.e., the employment of persons with disabilities, access to assistive technologies was considered in this article from the perspective of enabling people with disabilities to acquire the skills and knowledge required to gain employment. The primary interest was the availability of ATs in relation to (a) the accessibility of the urban environment and the environments within enterprises or organizations, and (b) the physical accessibility of the workplace (adaptation to the needs of disabled). Consequently, we considered the situation regarding ATs in each of these areas.

\subsection{Accessibility of the Urban Environment and the Environment within Enterprises}

In order to realize their potential, a person with a disability first needs to get to the place of work. In 2017, the Ministry of Labor reported that the share of social, transport, and engineering infrastructure facilities accessible to persons with disabilities in the total number of primary facilities increased to $57.8 \%$ [20]. At the same time, the situation regarding the accessibility of the urban environment in Moscow was much better than in other regions of Russia. In recent years, there have been significant changes, including all entrances to residential buildings, as well as social infrastructure facilities, being equipped with ramps, the premises of educational, medical, and other similar institutions being equipped with lifting mechanisms, and doorways for wheelchairs being expanded. The low-floor public transport is being introduced in the city, wheelchair access is provided for some subway lines, sidewalks are equipped with relief tiles, and traffic lights are provided with sound signals, etc. The scale and speed of positive changes were noted by our experts:

"What was 10 years ago and what is now?! We are really moving forward, we are catching up with positive experience, such as European one." (Head of the public organization of persons with disabilities-6) [18] (p. 37)

"In Moscow, the environment has indeed become a little more accessible: contrasting stairs, Braille inscriptions, etc." (Head of the public organization of persons with disabilities-5) [18] (p. 38)

The content analysis of media materials showed that the majority of the publications dealing with the problem of employment of persons with disabilities in Moscow are focused on the issues of accessibility of the urban environment- $38.4 \%$ of all the publications. Two-thirds of the publications showed the accomplishments, presenting the enhancements of the city's public transport vehicles as well as "social" taxi services to meet the needs of people with disabilities (special spaces for wheelchairs, assistance from drivers, as well as large print sand duplicated Braille inscriptions). They covered such subjects as providing the disabled with technical means of rehabilitation at the expense of the municipal budget (in particular, the directive of the Mayor of Moscow to develop a program that would introduce electronic vouchers/payments for people with disabilities, taking into account the real cost of such means), simplifying the procedure to obtain compensation for using guide dogs, launching a service to provide translation from sign language into Russian for the hearing impaired and deaf visitors to government agencies, resettlement of persons with disabilities to new, properly equipped apartments within the program of urban housing renovation, etc.

At the same time, one third of publications contained criticism as well. Mostly, this pointed out that although formally assistive technologies are implemented, they do not really work:

"However, even in the places where something seems to be done, people cannot always use the available equipment. I mean dangerous ramps; tactile tiles on the sidewalks sometimes leading to nowhere; 
non-functioning devices for the deaf and the blind. Apparently, this situation is the result of the lack of a clear system of State control." [21] (p. 2)

"In 2016 the Government of Russia adopted a decree on measures to adapt residential premises and common areas in apartment buildings to meet needs of people with disabilities. However, in practice this decree does not work. In general, only new residential housing meets the accessibility requirements, while the existing residential buildings are not adapted to the needs of persons with disabilities. In our opinion, first of all, it is necessary to install lift platforms and ramps in the existing housing. The process of providing adapted housing to people with disabilities is extremely bureaucratic (it is necessary to provide a lot of documents and certificates of income and property not only for the disabled but also for their relatives)." [22] (p. 4)

"Using metal descents in underground passages can only be done by professional stuntmen. An elevator in the underground passage can only be pre-booked by phone." [23]

Our experts spoke about the same issues:

"Imagine we are going to the cinema in a modern shopping center: 4 healthy men push a disabled person in a wheelchair because there is a 45-degree ramp. Sometimes ramps seem to be placed only for report." (Head of the rehabilitation institution for people with disabilities-2) [18] (p. 37)

"There is a special elevator installed in a passage in the subway. But it is locked up and nobody can use it. When an inspection comes it is turned on and the moment that the inspector leaves it is turned off and locked up again. Please install a standard elevator! Surely it costs a little bit more but it will be used constantly (not only by the disabled but also by moms with wheelchairs, by seniors, etc.). Meanwhile unused special elevator will rust, go out working conditions and eventually thrown out." (Head of the public organization of persons with disabilities-4) [18] (p. 38)

"For wheelchair users, the environment has become more accessible only in part. The service of mobility assistants has been introduced in the subway. But getting on the subway with wheelchairs is still a problem. Use of wheelchair on subway escalator is simply not impossible-it is dangerous even with the assistants' help. There are also restrictions on a person's weight-subway personnel can refuse to lift a person in a wheelchair. There are elevators on some stations but not in the city center. How is it actually possible to exit the subway then? The buses became more accessible but not on all routes. The driver of low-floor bus does not always stop where it is needed; he does not always get out and open the door for the wheelchair to enter. There is no accessibility for the blind and visually impaired, although we proposed the program "Talking City" - when it is announced which number of the bus is coming up." (Employee of a non-governmental organization that assists in the employment of persons with disabilities-1) [18] (p. 37)

Insufficient availability of special technical devices to persons with disabilities was mentioned as well:

"In theory, wheelchair should be provided by the State. Yet, applications to get it by the persons with disabilities are rejected time after time." [24]

The results of the content analysis of media materials and expert interviews corresponded to the results of the mass survey of people with disabilities. As it turns out, inaccessibility to the workplace is the second most frequent reason for the rejection of work offered (19.7\% of respondents). For those that are visually impaired as well as those with locomotory problems, the issue of transport accessibility is particularly acute. One quarter of the visually impaired $(24.2 \%)$ and almost as many disabled people with locomotory problems $(22.7 \%)$ had to refuse offered employment. The problem of transport accessibility was less likely to be the reason for the rejection of employment offer by people with hearing disabilities (8.7\%) and mental disabilities (10.4\%). In the latter case, this may be due to the 
fact that they do not move around the city without help at all. In addition, almost one fifth of the respondents (18.6\%) who worked within the past five years but were dissatisfied with their work, at least to some extent, attributed it to the fact that it was challenging to get to work [18] (p. 28).

As for the environments within enterprises (stairs, elevators, etc.), according to the analyzed data, inaccessibility as a reason for the refusal of the proposed work was indicated by $4.5 \%$ of the disabled respondents. More often than others, this reason was indicated by people with impaired vision $(4.5 \%)$ and with locomotory disorders (7.1\%). Another reason was the lack of special assistants, who are mostly needed by visually impaired and people with mental or cognitive impairments. While in the total sample $1.7 \%$ of respondents indicated this reason for refusing to work, $3.0 \%$ and $3.1 \%$ of visually and mental or cognitive impairments refused to work for this reason, respectively [18] (pp. 44-48).

\subsection{Accessibility of Workplaces}

One of the most significant barriers to employment was the inaccessibility of assistive technologies directly in workplaces. A total of $11.6 \%$ of people with disabilities indicated that they refused work because the organization of the workplace did not take into account their health status. This was particularly indicated by visually impaired persons (12.1\%), people with intellectual disabilities, and those with mental health issues (13.5\%).

In 2013, Russia adopted a federal law ${ }^{1}$ that defined the basic requirements for equipping special work stations for disabled employees, taking into account their impaired functions. However, according to the Federal State Statistics Service, more than a quarter of disabled workers (26.2\%) aged 15 and older were not satisfied to some extent with the working conditions in 2016 [16].

In the course of our survey, the respondents were asked to name the reasons for dissatisfaction with their work. More than a quarter of respondents (27.0\%) indicated that the conditions and/or the mode of work did not correspond with the state of their health. It is worth noting that among those who indicated this reason, there were relatively few (9\%) disabled people who were officially established in the first group of disability (disabled people with the greatest health problems), whereas almost $30 \%$ of disabled people in groups II and $\mathrm{III}^{2}$ indicated this reason. This is a comparatively large amount; therefore, this reason is one of the main reasons for such people leaving their jobs [18] (p. 28).

Experts also noted the problems with adapted workplaces' organization:

"There are still many barriers: the physical inaccessibility of many work facilities and the lack of information about the creation of special conditions at the workplace itself." (An employee of a non-governmental organization that assists with the employment of persons with disabilities-1)

However, some of employers talked about positive experiences:

"We bought a special table or chair with armrests convenient for people with locomotor disorders, as well as a special system (bracelets) for the hearing-impaired - so that in case of evacuation they were properly notified. Since we have hearing impaired people in the store, we decided to conduct sign language lessons for employees who want to communicate with their colleagues in sign language." (Employer-4) [18] (pp. 60-61)

Both employers and heads of public organizations of persons with disabilities said that ATs related to computer technology are becoming more accessible:

1 Federal Law of 2 July 2013 No. 168- $\phi 3$ “On Amendments to Articles 4 and 22 of the Federal Law "On the Social Protection of Disabled Persons in the Russian Federation".

2 In Russia, there are three groups of disability, depending on the severity of the disease and the degree of their influence on disability. The first group of disability includes the disabled with the most severe diseases, the third with the least severe diseases. This division into disability groups was introduced at the beginning of the Soviet power. In 1921, a "rational" classification of disability into six groups was introduced, and subsequently in 1923, this was replaced by a new classification, including the three disability groups. 
"They showed me an app where a person can say something, and an icon on the screen translates it into sign language or vice versa. You can also use it together with the online translator. It's a free app today." (Employer-1) [18] (p. 60)

The same is true for the visually impaired:

"Thanks to modern technologies, many professions have become available for the blind. For example, this is of much help for an informational service desk operator. Moreover, the visually impaired began to work as good as their colleagues. Thus, the only thing that is necessary is the existence of a service that would analyze the software being developed and provide recommendations for more expedient integration with non-visual screen access programs. Basically, now a blind specialist needs only a non-visual screen access program to work. Today these programs have reached such a level that a person can work without a special braille display and other technical means." (Head of the public organization of persons with disabilities-5)

However, the quality of the equipment and the range of opportunities they provide seriously depends on the price:

"Now there are two main programs of this kind. One of them costs about 40,000 rubles [this is about \$620; an average monthly salary in Russia in the year 2018 was about \$440], and the other one is free. Using this free program, most of the functions can be performed on a computer designed for the consumer market, that is, without spending money on additional digital equipment." (Head of the public organization of persons with disabilities-5)

Similar information about the high price for the average Russian citizen and, moreover, for people with disabilities, of the smallest Braille display consisting of only 14 characters, was also reported by M. Roshchina, the head of the Education Center for blind and visually impaired students at Nizhny Novgorod Lobachevsky State University. According to her, due to the high cost of modern technology, a majority of blind users can only work with the help of sound equipment [25].

Moreover, the data from the mass survey conducted by us suggest that, on the whole, the availability of computer technology for people with disabilities (not only for the blind) is limited due to financial reasons. A quarter of all disabled persons in Moscow surveyed by us (25.3\%) did not use a computer due to a lack of money to purchase it (those who did not use the Internet for the same reason made up $3.7 \%)$. Moreover, the majority of persons with disabilities $(81.2 \%)$ worked on a computer, including $16.5 \%$ who used professional programs (accounting, etc.), and 3.2\% who used a computer at the level of an information and communications technology specialists. Another problem was also discovered: More than half of disabled people would like to work remotely, but $14.8 \%$ say that this is not possible due to the low quality of the Internet connection available at home (unstable and/or expensive traffic). Another problem that was revealed was that, while the majority of people with disabilities were aware of their insufficient computer skills and would like to improve them, they did not know where and how to accomplish this. Among other things, this brings us to the state of education. As Roschina points out, according to the plans for inclusive education, if blind children enrolled in general schools en masse, teachers would be required to possess special skills regarding computer use to teach the visually impaired, despite the fact that "there is no regular training of specialists combining knowledge in the field of tiflopedagogics and tiflo information technologies in our country" [25].

The introduction of efficient assistive technologies is also hampered by procurement procedures for state and municipal needs. The main customers of the services provided by organizations that develop and equip workplaces for people with disabilities are government bodies, due to the fact that enterprises in need of such equipment often work with public organizations that represent people with disabilities and do not have enough of their own funds. Since 2013, the law has required such procurement procedures to be carried out using an open tender. Unfortunately, the tender system is designed in such a way that the main criterion for selecting a supplier is usually a low price, which often negatively affects the quality of the assistive technologies being purchased. For example, among the 
losers of the tender is a scientific institute that has long been engaged in the development of assistive technologies and has considerable experience in equipping them with workplaces:

"We had an idea of creating catalogs of adaptive techniques that would explain to the blind which equipment and how they can use. We analyzed all the equipment, chose those accessible for the blind, calculated the cost of creating descriptions and catalog layout, its publication in an enlarged font and in Braille, creating catalog in audio format as well as its online version. The idea was supported by the Moscow Department of Labor and Social Protection. Yet, the tender was won by the organization with no experience in this sphere-the marketing department of a construction company. This organization suddenly lowered the price and, thus, won the tender. They simply took the information from the Internet (that is, they did not plan any assessments or development) and included only printing costs and some other minor things in their price." (Head of the organization engaged in the development and implementation of assistive technologies-4)

"The Moscow Department of Labor and Social Protection is practically in despair. They say that financial resources allow them to buy good wheelchairs for people with disabilities but because of the specifics of the law on state and municipal procurement, only those suppliers who offer cheaper Chinese wheelchairs of lower quality benefit." (Head of the organization engaged in the development and implementation of assistive technologies-4)

This study showed that Russian employers are not seeking to create adapted workplaces for persons with disabilities. Mandatory quotas to increase the motivation of employers to employ persons with disabilities were introduced, alongside penalties for not meeting the quotas. However, in Russia this tool does not work properly. Experts pointed out that the quota size is too small (in Moscow it is $2-4 \%$ for an organization with 100 or more employees), there is poor control over the filling of quotas, and the fines were low (fines vary from 5000 to 10,000 rubles, or about $\$ 77-\$ 154$ ); this means that it is easier for employers to pay a fine than to spend money on employing disabled people and adapting the environment of the enterprise [26]. Wider access to assistive technology in the workplace can provide specialized enterprises for people with disabilities. This is, among other things, due to the effect of scale, e.g., by equipping a large number of work places at once, creating a special adaptation department, developing a unified scheme of working space equipment, taking into account the characteristics of conditions of various persons with disabilities, processing more information regarding the possibilities of introducing assistive technologies, entering into contracts for acquisition and maintenance of special technical and software products on more favorable terms, etc. According to the survey data, $5 \%$ of the respondents in the sample worked in such specialized enterprises in the last five years. The people who were most satisfied with their work were among those who worked in enterprises created by public organizations of people with disabilities, a proportion of $90.4 \%$ (only $6.4 \%$ were not satisfied and the rest were unsure regarding their answer). Much less satisfied people were among the employees of state and municipal enterprises, a proportion of $79.8 \%(12.8 \%$ were not satisfied). Even less satisfied people were among the employees of private organizations, which made up $75.4 \%$ (15.8\% were not satisfied).

During the Soviet period, the employment of persons with disabilities in specialized enterprises was very successful. After the Russian economy was transferred to a marketing one and there was a sharp reduction in the required state support, many specialized enterprises closed down or suffered significant losses. As experts note, the majority of such enterprises today that were once famous for their products, from the All-Russian Association of the Blind and the All-Russian Society of the Deaf to small craft workshops, are experiencing hard times:

"Today these enterprises are similar to the usual commercial enterprises. Yet, the work of the blind is obviously not competitive, labor productivity is obviously lower, and, according to the law, they work an hour less. Still almost all tax privileges were canceled, the state order for their products ceased. In 1991, 55,000 blind people worked at the enterprises of the All-Russian Association of the 
Blind, now there are 4,300. We conducted surveys among visually impaired people: about 5,000 people would like to work at such enterprises as well. Even facing the crisis, the economy is able to provide our enterprises with proper benefits and government orders. Lack of job opportunity leads to moral degradation of the visually impaired." (Head of the public organization of persons with disabilities-5) [18] (p. 65)

This difficult economic situation does not allow specialized enterprises to be modernized or for an acceptable level of wages to be maintained:

"The products they produce are outdated. It is necessary to be modernized because the All-Russian Association of the Blind has many products that a robot can make today (electrical outlets, etc.) but this is more quickly, cheaper, and with better quality." (Head of the public organization of persons with disabilities-1) [18] (p. 64)

"We need a decent salary — at least about 12,000-15,000 rubles a month (or about \$180-230). Today, such a salary is not at all enterprises. Many enterprises do not work full time. As a result, the blind get 3000-5000 rubles a month (or about \$50-\$70)." (Head of the public organization of persons with disabilities-5) [18] (p. 64)

"The number of enterprises under the All-Russian Society of the Deaf is markedly decreased. This happens because a deaf but in all other respects healthy man will not work for 7000 rubles (about \$100). The blind go there because they simply have nowhere else to go. But young blind people show themselves very well when working on a computer with sound programs. They are engaged in market analysis and consulting. We hope that the blind will also be able to come and say: "Sorry, I'm not going to work for seven thousand rubles!" (Head of the public organization of persons with disabilities-7) [18] (pp. 64-65)

\section{Discussion}

Our data suggest that the situation regarding the accessibility of assistive technologies is rather contradictory. On the one hand, there is some progress related to Russia's fulfillment of its obligations connected with ratification of the UN Convention on the Rights of Persons with Disabilities. Legislation that regulates the provision of ATs for people with disabilities is improving; the State program entitled "Accessible Environment" was adopted and implemented and the provision of ATs to people with disabilities is growing in quantitative terms, etc. On the other hand, the obtained information suggests that there are serious problems in each considered aspect of building up the labor potential of persons with disabilities. Serious problems for employment are related to insufficiently accessible urban environments. There is obvious progress regarding public transport (although this is far from being sufficient), but at the same time, there are serious complaints about the quality of ramps, not to mention the lack of elevators in apartment houses built in the 1960s-1970s, etc.

As for employment, the problems are associated primarily with the ineffectiveness of both positive and negative incentives designed to motivate employers to create adapted jobs and the lack of necessary state support for specialized enterprises for those categories of people with disabilities who can hardly be employed in the open labor market or those with no opportunities.

Financial barriers remain serious obstacles to the inclusion of persons with disabilities in the labor market. Most persons with disabilities do not have the means to acquire modern assistive technologies (moreover, not everyone has the financial capacity to purchase a computer or an Internet connection of the required quality for remote employment). Even more regrettably, our and others' data shows irrational spending of budget funds due to the specifics of tenders, as well as the bureaucratic, inflexible approach to drawing up lists of state-subsidized assistive technologies offered to persons with disabilities [3] (p. 2).

Among other serious barriers to the use of modern assistive technologies by persons with disabilities are problems regarding medical and social systems' operation. The experts we interviewed 
repeatedly pointed to the conservatism of the specialists of these services and their lack of information regarding modern assistive technologies that could significantly expand employment opportunities for persons with disabilities (this fact was also noted by other researchers [3] (p. 4).) It is not by chance that our experts representing the societies of persons with disabilities suggested including them in the commissions that determine the ability of persons with disabilities to work.

\section{Conclusions}

The published data show that Russia is in the process of actively introducing assistive technologies, however, our research shows that many ATs are still inaccessible. Though formally they may be implemented, the process does not work in reality. Limited access to ATs reduces the possibility of self-fulfillment of people with disabilities regarding productive work and impedes their well-being. Lack of income, in turn, blocks access to more modern and high-quality ATs. Revealed interweaving of social, economic, and infrastructural factors confirmed the feasibility of an approach to the implementation of assistive technologies as an ecosystem, in which seemingly peripheral aspects play no less a role than the technical capabilities of a society that provides assistive technology to people with disabilities [27].

In conclusion, it is worth noting that the problems we identified are not specific to the capital region. Some problems are of a general nature (for example, the situation with specialized enterprises, employers' attitudes, the specifics of medical and social expertise, etc.). With regard to problems related to the accessibility of environments and the ability of with disabilities to acquire more modern ATs, there is reason to assume that in the Russian provinces these are even more aggravated, due to the scarcity of most regional budgets (the budgetary provision of Moscow residents is ten times higher than the provinces) and lower standards of living for these populations.

Yet, these problems will have to be solved; inclusion of people with disabilities into Russian society requires a further increase in the accessibility of collective and individual assistive technologies.

Author Contributions: Conceptualization, methodology, O.A. and Y.N.; resources, data curation, writing—original draft preparation, Y.N.; writing-review and editing, project administration, O.A.

Funding: This research was funded by Department of Labor and Social Protection of the Population of Moscow.

Conflicts of Interest: The authors declare no conflict of interest. The funders had no role in the design of the study; in the collection, analyses, or interpretation of data; in the writing of the manuscript, or in the decision to publish the results.

\section{References}

1. World Health Organization. Assistive Technology. Available online: https://www.who.int/news-room/factsheets/detail/assistive-technology (accessed on 1 June 2019).

2. World Health Organization. Convention on the Rights of Persons with Disabilities. Available online: https://www.un.org/development/desa/disabilities/convention-on-the-rights-of-personswith-disabilities.html (accessed on 1 June 2019).

3. Pishnyak, A.; Goryainova, A.; Tochilina, E. Izuchenie Faktorov Razvitiya Ry‘nka Assistivny‘x Texnologij i Ustrojstv v Rossii: Analiz e'Kspertny'x Interv'yu [Study of the Factors of Development of the Market of Assistive Technologies and Devices in Russia: An analysis of Expert Interviews]. In XVIII Aprel'Skaya Mezhdunarodnaya Nauchnaya Konferenciya po Problemam Razvitiya e'Konomiki i Obshhestva [XVIII April International Scientific Conference on the Problems of the Development of the Economy and Society]; National Research University Higher School of Economics: Moscow, Russia, 2017. Available online: http://pensionreform.ru/121489 (accessed on 28 March 2019). (In Russian)

4. USSR Law. On the Basic Principles of Social Protection of Disabled Persons in the USSR. No 1826-1. 11 December 1990. Available online: http://www.consultant.ru/cons/cgi/online.cgi? req=doc\&base=ESU\&n= 3492\#041258785332308345 (accessed on 1 June 2019). (In Russian) 
5. Nagornova, A.Y.; Makarova, T.A. Istoricheskij Analiz Problemy Invalidnosti v Dorevolyucionnoj Rossii [Historical Analysis of Disability Problem in Pre-Revolutionary Russia and the USSR]. Available online: https:/cyberleninka.ru/article/v/istoricheskiy-analiz-problemy-invalidnosti-vdorevolyutsionnoy-rossii-i-sssr (accessed on 1 June 2019). (In Russian)

6. Federal Law. On Social Protection of Disabled Persons in the Russian Federation. 24 November 1995. N181- $\phi 3$. Available online: http://www.consultant.ru/document/cons_doc_LAW_8559/ (accessed on 1 June 2019). (In Russian)

7. Order of the Government of the Russian Federation. On the Federal List of Rehabilitation Measures, Technical Means of Rehabilitation and Services Provided to a Disabled Person. 30 December 2005; N 2347-p. Available online: http://docs.cntd.ru/document/901962331 (accessed on 1 June 2019). (In Russian)

8. Resolution of the Government of the Russian Federation. On the Procedure for Providing Disabled People with Technical Means of Rehabilitation and Providing Certain Categories of Citizens from among Veterans with Prosthetic and Orthopedic Products. 7 April 2008; N 240. Available online: https://base.garant.ru/12159775/ (accessed on 1 June 2019). (In Russian)

9. Klochkova, E.N.; Darda, E.S. Rynok Assistivnyh Tekhnologij i Ustrojstv: Statisticheskaya Ocenka Sostoyaniya [Market Assistive Technology and Devices: Statistical State Assessment]. In Rossiya: Tendencii i Perspektivy Razvitiya [Russia: Trends and Development Prospects]; Institute of Scientific Information for Social Sciences of the Russian Academy of Sciences: Moscow, Russia, 2017; pp. 668-672. (In Russian)

10. Nierling, L.; Maia, M.J. Assistive Technologies for People with Disabilities: Part. III: Perspectives on Assistive Technologies; European Parliamentary Research Service, Scientific Foresight Unit: Brussels, Belgium, 2018; p. 104. Available online: http://www.europarl.europa.eu/RegData/etudes/IDAN/2018/603218/EPRS_ IDA(2018)603218(ANN3)_EN.pdf (accessed on 31 March 2019).

11. Resolution Adopted by the General Assembly. Transforming Our World: The 2030 Agenda for Sustainable Development. 25 September 2015. Available online: https://www.un.org/en/development/desa/population/ publications/2030_Agenda_en.pdf (accessed on 1 June 2019).

12. Federal Law. On Amendments to Certain Legislative Acts of the Russian Federation on Social Protection of Disabled Persons in Connection with the Ratification of the Convention on the Rights of Persons with Disabilities. 1 December 2014. No. 419- $\phi 3$. Available online: http://www.consultant.ru/document/cons_doc_ LAW_171577/ (accessed on 1 June 2019). (In Russian)

13. Decree of the Government of the Russian Federation. On Approval of the State Program. of the Russian Federation "Accessible Environment" for 2011-2020. 1 December 2015; No. 1297. Available online: http: //static.government.ru/media/files/6kKpQJTEgR1Bmijjyqi6GWqpAoc6OmnC.pdf (accessed on 1 June 2019). (In Russian)

14. Natsun, L.N. Podderzhivaemoe Trudoustrojstvo Invalidov: Obzor Mirovogo Opy`ta [Supported Employment of Persons with Disabilities: A Review of Worldwide Experience]. In Bulletin of Ural Federal University. A Series of Economics and Management; Ural Federal University: Yekaterinburg, Russia, 2017; Volume 16, No 4; pp. 663-680. Available online: http://www.volnc.ru/files/www/research/grant161800078/publications-2017/ nacun.pdf (accessed on 31 March 2019). (In Russian)

15. World Health Organization. World Report on Disability. Geneva, Switzerland, 2011. Available online: https://www.who.int/disabilities/world_report/2011/report.pdf (accessed on 1 June 2019).

16. Federal State Statistics Service. Trud i Zanyatost' Invalidov [Work and Employment of People with Disabilities]. Available online: http://www.gks.ru/wps/wcm/connect/rosstat_main/rosstat/ru/statistics/ population/disabilities/\# (accessed on 26 March 2019). (In Russian)

17. Ministry of Labor of the Russian Federation. Ministr Maksim Topilin: Pered Nami Stoit Zadacha Uvelichit Chislennost' Zanyaty'x Invalidov do 50\% [Minister Maxim Topilin: We Are Faced with the Task of Increasing the Number of Employed Disabled People to 50\%]. Available online: https://rosmintrud.ru/employment/ resettlement/1 (accessed on 29 March 2019). (In Russian)

18. Alexandrova, O.A.; Nenakhova, Y.S. Trudoustrojstvo Invalidov na Stolichnom Ry'nke Truda: Problemy' $i$ Puti Resheniya [Employment of Persons with Disabilities in the Capital's Labor Market: Problems and Solutions]; ANO Council for Management and Development: Moscow, Russia, 2018; p. 280. Available online: http://www.isesp-ras.ru/images/monograph/2018_trudoustroystvo_invalidov_na_ stolichnom_rynke_truda.pdf (accessed on 31 March 2019). (In Russian) 
19. According to Medialogia. The Data is for April 2018. Ratings. Available online: http://www.mlg.ru/ratings/ media/federal/5997/ (accessed on 10 June 2018).

20. Ministry of Labor of the Russian Federation. Otchyot o Xode Realizacii i Ob Ocenke e'Ffektivnosti Gosudarstvennoj Programmy‘ Rossijskoj Federacii “Dostupnaya sreda” Na 2011-2020 Gody` Za 2017 God [Report on the Implementation and Evaluation of the State Program of the Russian Federation "Accessible Environment" for 2011-2020 for 2017]. Available online: https://rosmintrud.ru/docs/mintrud/handicapped/ 269 (accessed on 28 March 2019). (In Russian)

21. Zotova, E. Zakonodatel'stvo v Processe Nastrojki [Legislation in the Process of Setting Up]. Russky Invalid; Moscow City Organization of the All-Russian Society of Disabled People: Moscow, Russia, April 2017; No 298. Available online: http://www.rus-inv.ru/archive/2017/RI_04_17.pdf (accessed on 28 March 2019). (In Russian)

22. Terentyev, M. Vmeste Menyaem Obshchestvo k Luchshemu [Together We Are Changing Society for the Better]. Russky Invalid; Moscow City Organization of the All-Russian Society of Disabled People: Moscow, Russia, March, April 2018; No 309-310. Available online: http://www.rus-inv.ru/archive/2018/RI_03-04_18.pdf (accessed on 28 March 2019). (In Russian)

23. V Moskve Otkazalis' Zapuskat' Pod"Emnik Okolo Pod"Ezda Dlya Devushki-Invalida [Moscow Refused to Launch a Lift Near the Entrance for a Disabled Girl]. Newsru.com; Newsru.com: Moscow, Russia, 20 April 2018. Available online: https://msk.newsru.com/article/20apr2018/invalift.html (accessed on 28 March 2019). (In Russian)

24. Starova, I. Kak Zhivyotsya Invalidam v Rossii? [How Do People with Disabilities Live in Russia?]. In Echo of Moscow; Radio station Echo of Moscow: Moscow, Russia, 13 October 2017. Available online: https://echo.msk.ru/blog/eirenes/2073170-echo/) (accessed on 28 March 2019). (In Russian)

25. Alexandrova, O.A.; Nenakhova, Y.S. Metodologiya Statisticheskogo Analiza, Ocenki i Prognozirovaniya Polozheniya Invalidov na Stolichnom Ry'nke Truda [Methodology of Statistical Analysis, Assessment and Prediction of the Situation of Persons with Disabilities in the Capital Labor Market]; ANO Council for Management and Development: Moscow, Russia, 2018; p. 168. Available online: http://www.isesp-ras.ru/images/monograph/2018_ metodologiya_stat_analiza_polozh_invalidov_na_rynke_truda.pdf (accessed on 31 March 2019). (In Russian)

26. Kavokin, S. Professional`Naya Reabilitaciya Invalidov v Rossii [Kavokin S. Professional Rehabilitation of Disabled People in Russia]. Index. No 28. 2008. Available online: http://index.org.ru/journal/28/kavokin.html (accessed on 28 March 2019). (In Russian)

27. Banes, D. An Ecosystem Approach to Implementation of Assistive Technology. In Rehabilitation Technologies: Science and Practice; Federal Scientific Centre of Rehabilitation of the Disabled named after G.A. Albrecht: St. Petersburg, Russia, 2018; pp. 39-41. Available online: http://rehabperm.ru/wp-content/uploads/2018/05/ Sbornik.pdf (accessed on 26 July 2019). 